\title{
A TRANSAÇÃo PENAL À LUZ dA HERMENEUTICA CONSTITUCIONAL E PROCESSUAL PENAL
}

\author{
PENAL TRANSACTION IN THE LIGHT OF CONSTITUTIONAL AND PENAL \\ PROCEDURES HERMENEUTICS
}

\section{Cleverton Paulo das Chagas ${ }^{1}$ \\ Bruno Smolarek Dias ${ }^{2}$}

\begin{abstract}
SUMÁRIO: Introdução; 1. Contextualização; 2. Noções gerais; 3. Competência dos juizados especiais criminais; 4. Princípios aplicáveis aos juizados especiais criminais; 5. A transação penal; 6. A sentença de homologação da transação penal; 7. Discricionaridade regrada do ministério público; 8. (in) constitucionalidade da transação penal; 9. Posicionamentos jurisprudenciais; Considerações Finais; Referências das Fontes Citadas.
\end{abstract}

\section{RESUMO}

Por esta pesquisa bibliográfica e empírica, buscar-se-á analisar, sob o aspecto histórico e dialético, o instituto despenalizante da transação penal, importante inovação trazida pelo legislador na lei dos Juizados Especiais Criminais, Lei 9099/95, numa tentativa de desburocratizar e tornar mais célere os procedimentos criminais. O ponto central da discussão estará no aspecto da constitucionalidade de tal instituto, o qual sofreu e vem sofrendo diversas críticas no mundo doutrinário, no que pese, segundo alguns, impor uma pena ao sujeito tratado como autor do fato sem nem ao menos ter previamente instaurado o processo ou the dado direito de defesa, caracterizando, assim, patente e manifesta violação aos princípios constitucionais e processuais penais do devido processo legal, da presunção de inocência, do contraditório e da ampla defesa. Analisar-se-á aspectos e argumentos trazidos pela jurisdição, doutrina e legislação vigente, procurando construir um raciocínio concreto e claro acerca do tema proposto, bem como uma conclusão que atenda aos objetivos a que o presente trabalho se propõe.

PALAVRAS-ChAVE: Transação Penal; Juizados Especiais Criminais; Devido

\footnotetext{
${ }^{1}$ Acadêmico do Curso de Direito da Universidade Paranaense - UNIPAR, Unidade Universitária de Francisco Beltrão - PR. E-mail: cpaulochagas@hotmail.com.

2 Doutor em Ciências Jurídicas pela Universidade do Vale do Itajaí - UNIVALI. Mestre em Direito pela Pontifícia Universidade Católica do Paraná - PUC-PR. Docente do Curso de Mestrado em Direito Processual e Cidadania e da Graduação em Direito da Universidade Paranaense - UNIPAR. Docente da Graduação da Faculdade Assis Gurgacz - FAG e Faculdade Sul Brasil - FASUL. E-mail: professorbruno@unipar.br.
} 
CHAGAS, Cleverton Paulo das e DIAS, Bruno Smolarek. A transação penal à luz da hermeneutica constitucional e processual penal. Revista Eletrônica Direito e Política, Programa de Pós-Graduação Stricto Sensu em Ciência Jurídica da UNIVALI, Itajaí, v.10, n.3, 20 quadrimestre de 2015. Disponível em: www.univali.br/direitoepolitica - ISSN 1980-7791.

Processo Legal; Contraditório; Ampla Defesa; Presunção de Inocência.

\begin{abstract}
For this literature and empirical research, will be seeking to analyze, from a historical and dialectical aspect, the despenalizante institute criminal transaction, an important innovation introduced by the legislature in the law of the Special Criminal Courts, Law 9099/95, in an attempt to reduce bureaucracy and expedite prosecutions. The central point of discussion will be the aspect of the constitutionality of such an institute, which has suffered and is suffering some criticism on doctrinal world, in spite of, according to some, impose a penalty to the subject treated as the author of the fact without even having previously established process, or given the right of defense, featuring, well, patent and manifest violation of criminal and constitutional principles of procedural due process, the presumption of innocence, and the adversarial legal defense. Aspects and arguments brought by jurisdiction, applicable law and doctrine will be analyzed in-and seek to build an objective and clear thinking about the proposed theme and a conclusion that meets the objectives of the present work proposes.
\end{abstract}

KEYWORDS: Criminal Transaction; the Special Criminal Courts; Due Process; Contradictory; Wide Defense; Presumption of Innocence.

\title{
INTRODUÇÃO
}

O presente trabalho de conclusão de curso tem como título "A transação penal à luz da hermenêutica constitucional e processual penal"; e assim, torna-se mister destacar os aspectos relevantes do trabalho em comento, buscando-se compreender os aspectos basilares que fundamentam a constitucionalidade, ou não, de tal instituto despenalizante.

Busca-se com a presente pesquisa refletir sobre a transação penal, que ocorre no Juizados Especial Criminal, confrontando-a com os princípios constitucionais e processuais penais, trazendo à baila a discussão acerca da constitucionalidade desse instituto, tão aplicado em nosso ordenamento jurídico.

A Constituição Federal Brasileira surgiu com o intuito de consagrar e efetivar os princípios fundamentais e basilares do Estado de Direito, compreendendo as garantias fundamentais e essenciais, protegendo o bem comum.

Após a promulgação da Carta Maior, todos os demais diplomas legais decorrem desta, devendo ser respeitada a hierarquia das normas, sendo a Constituição a 
CHAGAS, Cleverton Paulo das e DIAS, Bruno Smolarek. A transação penal à luz da hermeneutica constitucional e processual penal. Revista Eletrônica Direito e Política, Programa de Pós-Graduação Stricto Sensu em Ciência Jurídica da UNIVALI, Itajaí, v.10, n.3, 20 quadrimestre de 2015. Disponível em: www.univali.br/direitoepolitica - ISSN 1980-7791.

maior delas e todas as demais pautar-se por ela. Deste modo, todo ato que contrarie esta lógica estará sujeito à discussão de constitucionalidade. Este, por sinal, é um dos objetivos do presente trabalho, qual seja, a análise dos princípios constitucionais e processuais penais, correlacionando-os com a transação penal e, consequentemente, analisar se há ou não mácula dos mesmos. A transação penal, ao início, ofende ao devido processo legal, a ampla defesa, contraditório, indisponibilidade do interesse público, obrigatoriedade da ação penal e da presunção de inocência?

Em linhas gerais, busca-se avaliar se os Juizados Especiais Criminais têm competência constitucional de propor e aplicar a chamada transação penal, verificando se este procedimento é válido e, portanto, constitucional, caso contrário, delinear as contradições com a previsão legal magna.

Assim sendo, adentrando no bojo do trabalho, a primeira parte traz uma abordagem histórica e contextual, sendo analisado o cenário fático antes da criação da lei 9.099/95, que trata dos Juizados Especiais Civis e Criminais, bem como da competência para julgamento destes na atualidade.

Posteriormente, parte-se para uma análise principiológica dos Juizados Especiais Criminais, introduzindo a análise do instituto da transação penal como ferramenta de despenalização nos crimes tidos como de menor potencial ofensivo.

$\mathrm{Na}$ sequência, analisa-se propriamente a transação penal, inserida na Constituição Federal, disposta no art. 98, inciso I. Entretanto, o simples fato da previsão constitucional, basta para considerar um procedimento válido e, portanto, constitucional? Nessa esteira, a presente pesquisa propõe-se a responder a esta e demais indagações.

Isto posto, visa-se pontuar os aspectos relevantes à constitucionalidade ou inconstitucionalidade da transação penal, considerando todos os meios pesquisados e estabelecendo um comparativo com a Constituição Federal, em seus diversos aspectos. 
CHAGAS, Cleverton Paulo das e DIAS, Bruno Smolarek. A transação penal à luz da hermeneutica constitucional e processual penal. Revista Eletrônica Direito e Política, Programa de Pós-Graduação Stricto Sensu em Ciência Jurídica da UNIVALI, Itajaí, v.10, n.3, $2^{\circ}$ quadrimestre de 2015. Disponível em: www.univali.br/direitoepolitica - ISSN 1980-7791.

\section{CONTEXTUALIZAÇÃO}

O cenário precedente à lei dos Juizados Especiais Criminais era o de um poder judiciário abarrotado de processos. A necessidade de observância das regras do Código de Processo Penal, somado ao acúmulo de processos que tramitavam nas varas criminais espalhadas pelo Brasil, acabava por engessar e limitar o funcionamento do Judiciário, tornado o sistema demorado, burocrático e nem sempre justo.

A situação em que se encontrava o judiciário brasileiro é muito bem ilustrada nas palavras de CARVALHO:

Era humanamente impossível para um juiz conduzir todos os processos existentes na Comarca, ou Vara, trabalhando com um número tão elevado de feitos, o que obrigava 0 Magistrado, embora contra a sua vontade, a dar preferência aos casos mais graves, para só então cuidar do que hoje a Lei, implicitamente, chama de "pequenos crimes", ou "crimes anões", ou ainda na linguagem explícita da lei "Infrações de Menor Potencial Ofensivo" ${ }^{3}$.

Nesse sentido, assevera MIRABETE:

Com essa disposição, obrigando à criação dos Juizados Especiais, a Carta Constitucional deu margem a importantes inovações em nosso ordenamento jurídico penal e processual penal, aproveitando-se a experiência de instrumentos jurídicos já utilizados em vários países, como os Estados Unidos e Itália, destinados a desburocratização e simplificação da Justiça Penal. Deu-se resposta à imperiosa necessidade de o sistema processual penal brasileiro abrir-se às posições e tendências contemporâneas, possibilitando-se uma solução rápida para a lide penal, quer pelo consenso das partes, com a pronta reparação dos danos sofridos pela vítima na composição, quer pela transação, com a aplicação

\footnotetext{
${ }^{3}$ CARVALHO, Luiz Gustavo Grandinetti Castanho. Lei dos Juizados Especiais Criminais
}

Comentada, anotada e atualizada de acordo com a Lei 10.259/2001. 3 ed. Rio de Janeiro: Lúmen Júris. 2008. P. 35. 
CHAGAS, Cleverton Paulo das e DIAS, Bruno Smolarek. A transação penal à luz da hermeneutica constitucional e processual penal. Revista Eletrônica Direito e Política, Programa de Pós-Graduação Stricto Sensu em Ciência Jurídica da UNIVALI, Itajaí, v.10, n.3, 20 quadrimestre de 2015. Disponível em: www.univali.br/direitoepolitica - ISSN 1980-7791.

de penas não privativas de liberdade, quer por um procedimento célere para a apuração da responsabilidade penal dos autores de infrações penais de menor gravidade na hipótese de não se lograr ou não ser possível aplicar uma ou outra daquelas medidas inovadoras ${ }^{4}$.

Foi nesse contexto que surgiu a lei 9.099/95, visando tornar o processo mais célere, ao passo que, nas palavras do mesmo autor:

Passou-se, assim, a exigir um processo penal de melhor qualidade, com instrumentos mais adequados a tutela de todos os diretos, assegurando-se a utilidade das decisões jurídicas, bem como a implantação de um processo criminal com mecanismos rápidos, simples e econômicos de modo a suplementar a morosidade nos julgamentos de ilícitos menores desafogando a justiça criminal, para aperfeiçoar a aplicação da lei penal aos autores dos mais graves atendados aos valores sociais vigentes. O aumento da criminalidade, aliás, tornava inevitável que se relegasse a segundo plano pequenas infrações penais, passando a ter preferência no julgamento os crimes mais graves diante da necessidade de retirar do convívio social os elementos mais perigosos de outro lado ressalvasse a necessidade de um procedimento sumário para a apuração dessas infrações menores, dando pronta a resposta ao ato infracional e evitando as manobrar que levavam a porta liberatória da prescrição ${ }^{5}$.

Sem dúvida esse novo ordenamento rompeu com o modelo antigo de se fazer justiça, implantando um modelo inovador, mais eficaz e célere que o até então utilizado nos crimes de menor potencial ofensivo. Tal ordenamento, indubitavelmente, refletiu não somente nas infrações menos gravosas, mas, sim, em toda a estrutura do sistema penal brasileiro, ao passo que se por um lado

\footnotetext{
${ }^{4}$ MIRABETE, Julio Fabbrini. Juizados especiais criminais. 3. ed. São Paulo: Atlas S.A, 1998. P. 16.

${ }^{5}$ Ibidem.
} 
CHAGAS, Cleverton Paulo das e DIAS, Bruno Smolarek. A transação penal à luz da hermeneutica constitucional e processual penal. Revista Eletrônica Direito e Política, Programa de Pós-Graduação Stricto Sensu em Ciência Jurídica da UNIVALI, Itajaí, v.10, n.3, $2^{\circ}$ quadrimestre de 2015. Disponível em: www.univali.br/direitoepolitica - ISSN 1980-7791.

separou essas infrações afim de que sejam processadas e julgadas em um sistema minimalista, os juizados, por outro lado possibilitou que os crimes de maior relevância voltassem a merecer tratamento prioritário, mais eficaz, pelo Poder Judiciário, uma vez que as infrações denominadas de menor potencial ofensivo agora têm tratamento simples, informal e célere.

Acerca dessa nova mentalidade, pondera GRINOVER:

O legislador soube romper os esquemas clássicos do direito criminal e do processo penal, adorando corajosamente soluções profundamente inovadoras.

E os operadores do direito souberam conscientiza-se do dignificado e da importância da nova lei, aplicando-a com mentalidade renovada ${ }^{6}$.

No âmbito desse novo diploma legal, a lei 9.099/95, surge o instituto da transação penal, como ferramenta despenalizante, que possibilita que o autor do fato aceite abrir mão de do contraditório e da ampla defesa, cumprindo uma pena restritiva de direito, em troca de evitar um processo penal com consequências, talvez, mais gravosas.

\section{NOÇÕES GERAIS}

O instituto da transação penal como conhecemos hoje, surgiu com o advento da Lei 9.099/95, a qual concretiza o comando contido no artigo 98, inciso I, da Constituição da República.

Por este instituto, o indivíduo que pratica uma infração considerada de menor potencial ofensivo sujeita-se a pena restritiva de direito consistente em acordo com o Ministério Público, homologado judicialmente. Referido acordo, está previsto no artigo 76 da Lei 9.099/95 e aplica-se as infrações cuja ação penal seja pública condicionada ou incondicionada.

O $\S 4^{\circ}$ do mencionado preceito dispõe que o juiz acolherá a proposta aceita pelo autor do fato e emitirá sentença aplicando a pena negociada. Tal decisão não importará reincidência, nem produzirá efeitos civis e impede que o indivíduo se

${ }^{6}$ GRINOVER, Ada Pellegrini. FILHO, Antônio Magalhões Gomes. FERNANDES, Antônio Scarance. GOMES, Luiz Flávio. Juizados especiais criminais: comentários à lei 9.0955, de 26.09.1995. 4. ed. São Paulo: Revista dos Tribunais, 2002. P. 15. 
CHAGAS, Cleverton Paulo das e DIAS, Bruno Smolarek. A transação penal à luz da hermeneutica constitucional e processual penal. Revista Eletrônica Direito e Política, Programa de Pós-Graduação Stricto Sensu em Ciência Jurídica da UNIVALI, Itajaí, v.10, n.3, $2^{\circ}$ quadrimestre de 2015. Disponível em: www.univali.br/direitoepolitica - ISSN 1980-7791.

beneficie desse instituto por 5 anos a contar do termino do seu cumprimento.

De como geral, a transação penal, no âmbito da Lei dos juizados surgiu com dois propósitos: aliviar a sobrecarga das varas criminais comuns e tornar mais rápido e célere a tramitação das demandas que não envolvam questões complexas ou crimes de maior potencial ofensivo.

Nas palavras de GRINOVER:

A lei 9.099/95 de 26 de setembro de 1995, implementou o sistema dos Juizados Especiais Cíveis e Criminais no ambiente jurídico brasileiro, o qual aflorou da necessidade de processos mais céleres e da aplicação de penas pecuniárias aos crimes de menor potencial ofensivo. A lei 9.099/95, de 26.09.1995, como se percebe, inovou profundamente nosso ordenamento jurídico-penal. Cumprindo-se uma determinação constitucional (CF, art. 98, inciso I). Foi posto prática um novo modelo de justiça criminal. É uma verdadeira revolução (jurídica e de mentalidade), porque quebrou-se a inflexibilidade do clássico princípio da obrigatoriedade da ação penal. Abriu-se no campo penal um certo espaço para o consenso. Ao lado do clássico princípio da verdade material, agora temos que admitir também a verdade consensuada? .

A questão a ser debatida é acerca do conflito de princípios que surgiu com a criação da transação. De um lado, visualiza-se a celeridade e informalidade processual, evitando um apego excessivo ao formalismo ao tratar-se das infrações de menor potencial ofensivo. De outro lado, está o princípio do devido processo legal, do contraditório e da ampla defesa, os quais são mitigados quando o autor do fato aceita cumprir pena privativa de direito abrindo mão de seus direitos de defesa.

\footnotetext{
${ }^{7}$ GRINOVER, Ada Pellegrini. FILHO, Antônio Magalhões Gomes. FERNANDES, Antônio Scarance. GOMES, Luiz Flávio. Juizados especiais criminais: comentários à lei 9.0955, de 26.09.1995. 4. ed. São Paulo: Revista dos Tribunais, 2002. P. 45.
} 
CHAGAS, Cleverton Paulo das e DIAS, Bruno Smolarek. A transação penal à luz da hermeneutica constitucional e processual penal. Revista Eletrônica Direito e Política, Programa de Pós-Graduação Stricto Sensu em Ciência Jurídica da UNIVALI, Itajaí, v.10, n.3, $2^{\circ}$ quadrimestre de 2015. Disponível em: www.univali.br/direitoepolitica - ISSN 1980-7791.

\section{COMPETÊNCIA DOS JUIZADOS ESPECIAIS CRIMINAIS}

Compete aos Juizados Especiais Criminais apreciar Às infrações penais de menor potencial ofensivo, aos quais cabe a conciliação, a reparação do prejuízo e a transação. Cabendo, além da conciliação, o julgamento e execução de seus julgados.

Prevê o artigo 61 da lei 9.099/95, modificado pela lei 11.313/06: "Considera-se infrações penais de menor potencial ofensivo, para efeito desta lei, as contravenções penais e os crimes a que a lei comine pena máxima não superior a 2 (dois) anos, cumulada ou não com multa.". "Não se submetem a competência dos Juizados Especiais Criminais as infrações que têm procedimento especial, incompatível com o rito estabelecido na Lei 9.099/95".

Nesse sentido, o critério predominante no Juizado Especial é o material. Uma competência dada pela Constituição Federal, art. 98, I, com a seguinte redação:

Art. 98. A União, no Distrito Federal e nos Territórios, e os Estados criarão: I - Juizados especiais, providos por juízes togados, ou togados e leigos, competentes para a conciliação, o julgamento e a execução das causas cíveis de menor complexidade e infrações penais de menor potencial ofensivo, mediante os procedimentos orais e sumaríssimos, permitidos, nas hipóteses previstas em lei, a transação e o julgamento de recursos por turmas de juízes de primeiro grau $^{8}$.

Ainda, a fixação da competência decorre da natureza da infração e da não previsão de circunstancias especiais que desloque a causa para o Juízo Comum.

\section{PRINCÍPIOS APLICÁVEIS AOS JUIZADOS ESPECIAIS CRIMINAIS}

\subsection{Princípio da Celeridade}

Relaciona-se com a busca rápida de solução rápida para os conflitos da sociedade.

\footnotetext{
${ }^{8}$ BRASIL. Constituição (1988). Constituição da República Federativa do Brasil: Promulgada em 05 de Outubro de 1988. 8. Ed. São Paulo: Revista dos Tribunais, 2003.
} 
CHAGAS, Cleverton Paulo das e DIAS, Bruno Smolarek. A transação penal à luz da hermeneutica constitucional e processual penal. Revista Eletrônica Direito e Política, Programa de Pós-Graduação Stricto Sensu em Ciência Jurídica da UNIVALI, Itajaí, v.10, n.3, $2^{\circ}$ quadrimestre de 2015. Disponível em: www.univali.br/direitoepolitica - ISSN 1980-7791.

Trata da rapidez no processamento.

Visa evitar a protelação dos atos processuais, o que não significa a resolução imediata do conflito, mas impõe rapidez na prolação da decisão final.

De acordo com NOGUEIRA:

Portanto, a celeridade processual não está na pressa inconsequente, com soluções falhas, mas na rapidez necessária, dentro dos prazos razoáveis, religiosamente cumpridos. Não se queira ir de um extremo ao outro: de uma justiça morosa, injusta e descumpridora de prazos a uma justiça plantonista, imediata e falha, pois, aqui, a pressa é inimiga da perfeição ${ }^{9}$.

Nesse sentido, a celeridade presente nos procedimentos mais informais, tais como os Juizados Especiais Cíveis e Criminais, não corresponde a uma forma irresponsável de se fazer justiça, mas sim de uma forma que privilegie a rapidez comungada com a efetividade das decisões tomadas.

\subsection{Princípio da Oralidade}

Busca a concentração dos atos, evitando a utilização de documentos que possam implicar em demora, de modo que o pedido inicial pode ser oral e será reduzido em termo pela secretaria do Juizado (art. 14, § 30, da lei 9.099/95). Do mesmo modo, a contestação e o pedido contraposto também poderão ser apresentados oralmente.

Para NUCCI:

Sua aplicação, na lei 9.099/95, limita-se a documentos ao mínimo possível (arts. 65, caput, 67, 77, caput e $\S \S 1^{\circ}$ e $3^{\circ}$, e $\left.81, \S 2^{\circ}\right)$. As partes debatem e dialogam, procurando encontrar uma resposta penal que seja justa para o autor do fato e satisfaça, para o Estado, os fins da prevenção geral e especial $^{10}$.

\footnotetext{
${ }^{9}$ NOGUEIRA, Paulo Lucio. Juizados Especiais Cíveis e Criminais: comentários. São Paulo: Saraiva 1996. P. 73.

${ }^{10}$ NUCCI, Guilherme de Souza. Leis penais e processuais penais comentadas. 5. ed. São Paulo: Revista dos Tribunais, 2010. P. 71.
} 
CHAGAS, Cleverton Paulo das e DIAS, Bruno Smolarek. A transação penal à luz da hermeneutica constitucional e processual penal. Revista Eletrônica Direito e Política, Programa de Pós-Graduação Stricto Sensu em Ciência Jurídica da UNIVALI, Itajaí, v.10, n.3, $2^{\circ}$ quadrimestre de 2015. Disponível em: www.univali.br/direitoepolitica - ISSN 1980-7791.

Como demonstrado, por este princípio busca-se um maior alcance do poder judiciário, levando o acesso à justiça ao maior número de pessoas, inclusive aquelas que não teriam acesso a procedimentos mais burocráticos e formais como acontece no procedimento comum.

\subsection{Princípio da Economia Processual}

Por este princípio busca-se obter o máximo rendimento da lei com o mínimo de atos processuais, resultando na diminuição de gastos, tanto para o Poder Executivo quanto para o Poder Judiciário, visto que ante as peculiaridades do Juizado Especial Criminal, nem sempre o aparato judicial é acionado.

Nessa esteira, GRINOVER esclarece:

O princípio da economia processual informa praticamente todos os critérios aqui analisados, estando presente em todo o Juizado, desde a fase preliminar até o encerramento da causa: evita-se o inquérito; busca-se que o autor do fato e a vítima sejam desde logo encaminhados ao juizado; pretende-se que, através de acordos civis ou penais, não seja formado o processo; para a acusação, prescinde-se do exame de corpo de delito; as intimações devem ser feitas desde logo; o procedimento sumaríssimo resume-se a uma só audiência ${ }^{11}$.

Percebe-se que o princípio em comento, transforma os procedimentos de competência dos juizados especiais criminais mais rápidos e imediatos, o que, juntamente com os demais princípios, ameniza os efeitos prejudiciais que o conflito poderia ocasionar entre as partes do processo. Evita-se, assim, a pratica de atos demasiadamente longos, de modo que o objetivo principal é solucionar a demanda em verdadeiro combate aos atos meramente protelatórios, não raramente observados no procedimento comum.

\subsection{Princípio da simplicidade e informalidade}

${ }^{11}$ GRINOVER, Ada Pellegrini. FILHO, Antônio Magalhões Gomes. FERNANDES, Antônio Scarance. GOMES, Luiz Flávio. Juizados especiais criminais: comentários à lei 9.0955, de 26.09.1995. 4. ed. São Paulo: Revista dos Tribunais, 2002. P. 78. 
CHAGAS, Cleverton Paulo das e DIAS, Bruno Smolarek. A transação penal à luz da hermeneutica constitucional e processual penal. Revista Eletrônica Direito e Política, Programa de Pós-Graduação Stricto Sensu em Ciência Jurídica da UNIVALI, Itajaí, v.10, n.3, $2^{\circ}$ quadrimestre de 2015. Disponível em: www.univali.br/direitoepolitica - ISSN 1980-7791.

Por tal princípio, imprime-se ao processo um ritmo sem formalidades inúteis, buscando-se a finalidade do ato processual da forma mais simples possível.

Permite que o ato processual seja praticado de forma a dar agilidade ao processo.

\subsection{Princípio da imediação}

Decorre desse princípio a ideia de que apenas o juiz que participou da audiência preliminar poderá julgar o feito, corolário com o princípio da identidade física do juiz.

\subsection{Princípio da identidade física do juiz}

O juiz que colheu as provas deve ser o mesmo a sentenciar, salvo nas hipóteses de impossibilidade.

Para Aury Lopes Junior:

Deve o julgador dirigir pessoalmente a instrução processual, recolhendo elementos probatórios úteis à decisão, percebendo, sem qualquer intermediário, todo conjunto trazido aos autos. Entendemos que deve sempre fisicamente o mesmo magistrado, participando e dirigindo a colheita de provas e todos os atos necessários para deliberar, proferindo sentença com base em tudo que foi carregado ao feito, bem como tudo aquilo que pode aprender no curso do processo ${ }^{12}$. Corolário deste princípio, a doutrina majoritária trata do chamado princípio da identidade física do promotor, pelo qual, entende-se necessário que o promotor de justiça que participe da audiência preliminar seja o mesmo que ofereça a transação penal, suspensão condicional do processo ou, em casos extremos, que ofereça a denúncia contra o suposto autor do fato.

\subsection{Princípio da concentração dos atos}

\footnotetext{
12 JUNIOR, Aury Lopes, Direito processual penal. 9. ed. São Paulo: Saraiva, 2012. P. 320.
} 
CHAGAS, Cleverton Paulo das e DIAS, Bruno Smolarek. A transação penal à luz da hermeneutica constitucional e processual penal. Revista Eletrônica Direito e Política, Programa de Pós-Graduação Stricto Sensu em Ciência Jurídica da UNIVALI, Itajaí, v.10, n.3, $2^{\circ}$ quadrimestre de 2015. Disponível em: www.univali.br/direitoepolitica - ISSN 1980-7791.

Os atos praticados no processo devem ficar próximos uns dos outros.

Porém, a concentração não pode prejudicar o acusado, tendo os direitos que Ihe são assegurados pela lei - ampla defesa, contraditório, devido processo legal, nem a acusação, impedindo-a de fazer prova do que legal.

\section{A TRANSAÇÃO PENAL}

O instituto da transação penal é uma ferramenta que possui o juiz, de aplicar ao autor do fato, caso este e o Ministério Público aceitem, uma pena restritiva de direito, como por exemplo: prestação pecuniária, serviços à comunidade, multa, dentre outros previsto nos artigos 43 e 49, todos do Código Penal.

Dispõe o artigo 76 da lei 9.099/95:

Art. 76. Havendo representação ou tratando-se de crime de ação penal pública incondicionada, não sendo caso de arquivamento, o Ministério Público poderá propor a aplicação imediata de pena restritivas de direitos ou multas, a ser especificada na proposta.

$\S 10$ Nas hipóteses de ser a pena de multa a única aplicável, o juiz poderá reduzi-la até a metade.

$\S 20$ Não se admitirá a proposta se ficar comprovado: I - ter sido o infrator condenado, pela prática de crime, à pena privativa de liberdade, por sentença definitiva.

II - ter sido o agente beneficiado anteriormente, no prazo de cinco anos, pela aplicação de pena restritiva ou multa, nos termos desse artigo;

III - não indicarem os antecedentes, a conduta social e a personalidade do agente, bem como os motivos e as circunstâncias, a conduta social e a personalidade do agente, bem como os motivos e as circunstâncias, ser necessária e suficiência a adoção da medida.

(...) (Lei 9.099, 1995, Art. 76)

Inicialmente este artigo sugere tratar-se de pura faculdade do acusador, que poderá não oferecer a transação ao autor do fato, mesmo que presentes as 
CHAGAS, Cleverton Paulo das e DIAS, Bruno Smolarek. A transação penal à luz da hermeneutica constitucional e processual penal. Revista Eletrônica Direito e Política, Programa de Pós-Graduação Stricto Sensu em Ciência Jurídica da UNIVALI, Itajaí, v.10, n.3, $2^{\circ}$ quadrimestre de 2015. Disponível em: www.univali.br/direitoepolitica - ISSN 1980-7791.

condições do $\S 20$ do dispositivo.

Contrário à isto, alega GRINOVER:

No entanto, permitir ao Ministério Público (ou o acusado privado) que deixe de formular a proposta de transação penal na hipótese de presença dos requisitos do $\S 2^{\circ}$ do artigo 76, poderia redundar em odiosa discriminação, a ferir o princípio da isonomia e a reaproximar a atuação do acusador que assim se pautasse ao princípio de oportunidade pura, que não foi acolhida pela lei ${ }^{13}$.

Desse modo, a expressão "poderá" em verdade não indica mera faculdade, mas um poder-dever do Ministério Público, quando preenchidos os requisitos do art. 76 da lei 9.099/95.

Para a mesma autora, no caso de não oferecimento da proposta de transação penal pelo Ministério Público:

Tem-se surgido, a esse propósito, que ao poder-dever da acusação corresponderia um verdadeiro direito subjetivo público do autuado à apresentação da proposta de transação, uma vez não enquadrado o caso nas hipóteses do $\S 20$ do art. 76. E, para esse caso, a solução estaria então na formulação da proposta pelo Juiz que, havendo aceitação do autuado e de seu advogado, desde logo, a homologaria, nos termos do $\S 4^{0}$ do dispositivo ${ }^{14}$.

No que diz respeito ao oferecimento da proposta de transação penal, o Ministério Público deverá especificar os termos da proposta. Conforme GRINOVER:

A proposta da acusação deverá ser clara e precisa, para dar ao autuado e seu defensor pleno conhecimento da pena proposta, com a medida de suas consequências práticas. Referir-se-á ao fato narrado o termo de ocorrência, mas sem qualquer tipificação legal. Isso porque a aplicação da sanção

\footnotetext{
13 GRINOVER, Ada Pellegrini. FILHO, Antônio Magalhões Gomes. FERNANDES, Antônio Scarance. GOMES, Luiz Flávio. Juizados especiais criminais: comentários à lei 9.0955, de 26.09.1995. 4. ed. São Paulo: Revista dos Tribunais, 2002. P. 143.

${ }^{14}$ Idem. P. 144
} 
CHAGAS, Cleverton Paulo das e DIAS, Bruno Smolarek. A transação penal à luz da hermeneutica constitucional e processual penal. Revista Eletrônica Direito e Política, Programa de Pós-Graduação Stricto Sensu em Ciência Jurídica da UNIVALI, Itajaí, v.10, n.3, $2^{\circ}$ quadrimestre de 2015. Disponível em: www.univali.br/direitoepolitica - ISSN 1980-7791.

não indica reconhecimento da culpabilidade ${ }^{15}$.

Esta proposta é um mero projeto que o Ministério Público pode trazer pronto para a audiência de conciliação, que poderá nesta oportunidade ser modificado.

Em caso de concordância, o cumprimento da transação penal gera encerramento do processo.

\section{A SENTENÇA DE HOMOLOGAÇÃo DA TRANSAÇÃo PENAL}

Após aceita a transação penal pelo autor do fato e pelo seu defensor, bem como após a análise do juiz, a proposta é homologada.

Esclarece CAPEZ:

A transação não pode ser feita fora da audiência, no gabinete do representante do Ministério Público ou nas salas da Ordem dos Advogados (OAB), existentes nos juízos, e levada ao juiz para homologação, sem que o autor diga-lhe qualquer coisa. Os preparativos, as conversas, os entendimentos podem, é verdade, ser feito antes, mas na presença do juiz, tudo deve ser posto, e o autor do fato deve ser esclarecido pelo juiz, e livremente decidir. Assim deve ser feita a conciliação penal. Tudo transparentemente ${ }^{16}$.

Cabe salientar que o juiz não é mero homologador, mas poderá excluir ou incluir nova condição a proposta feita pelo Ministério Público e aceita pelo autor do fato. A lei dá tratamento diferenciado à sentença homologatória do acordo civil e a sentença homologatória da transação penal: a primeira é irrecorrível, enquanto a segunda é apelável.

\subsection{Natureza jurídica da sentença de homologação}

A sentença que aplica pena restritiva de direitos ou multa, com base no art. 76, da lei 9.099/95 não tem caráter nem condenatório nem absolutório, mas

\footnotetext{
${ }^{15}$ GRINOVER, Ada Pellegrini. FILHO, Antônio Magalhões Gomes. FERNANDES, Antônio Scarance. GOMES, Luiz Flávio. Juizados especiais criminais: comentários à lei 9.0955, de 26.09.1995. 4. ed. São Paulo: Revista dos Tribunais, 2002. P. 148.

${ }^{16}$ CAPEZ, Fernando. Curso de processo penal. 19. ed. São Paulo: Saraiva, 2012. P. 135.
} 
CHAGAS, Cleverton Paulo das e DIAS, Bruno Smolarek. A transação penal à luz da hermeneutica constitucional e processual penal. Revista Eletrônica Direito e Política, Programa de Pós-Graduação Stricto Sensu em Ciência Jurídica da UNIVALI, Itajaí, v.10, n.3, $2^{\circ}$ quadrimestre de 2015. Disponível em: www.univali.br/direitoepolitica - ISSN 1980-7791.

simplesmente homologatória da transação penal, declarando uma situação jurídica de conformidade penal bilateral.

Nesse sentido, sempre que as partes transigem, pondo fim à relação processual, a decisão judicial que legitima juridicamente essa convergência de vontades, não terá caráter condenatório, mas homologatório.

Esclarece GRINOVER:

A sentença que aplica a pena, em face do consenso dos interessados, não é absolutória nem condenatória. Trata-se simplesmente de sentença homologatória de transação penal, que não indica acolhimento nem desacolhimento do pedido do autor (que sequer foi formulado), mas que compõe a controvérsia de acordo com a vontade dos partícipes, constituindo título executivo judicial. São os próprios envolvidos no conflito a aditar a solução para sua pendência, observados os parâmetros da $l \mathrm{ei}^{17}$.

Em outras palavras, CAPEZ doutrina:

A natureza jurídica da sentença homologatória é condenatória, fazendo coisa julgada formal e material. Tratase, no entanto, de condenação imprópria, que mais se assemelha a decisão meramente homologatória, uma vez que não implica admissão de culpabilidade por parte do autor que aceita a proposta, mas decisão tomada com base em critérios de pura conveniência pessoal ${ }^{18}$.

Nesta esteira, embora tratada como sentença imprópria, dada a sua natureza essencialmente homologatória, a decisão que homologa a transação penal não deixa de ser uma sentença, ao passo que obriga o autor do fato a cumprir a prestação que foi acordada, aplicando-Ihe sanção no caso de descumprimento.

Deste modo, tem-se que a sentença homologatória de transação penal possui natureza condenatória, pois condena o indivíduo a cumprir com determinada obrigação.

\footnotetext{
17 GRINOVER, Ada Pellegrini. FILHO, Antônio Magalhões Gomes. FERNANDES, Antônio Scarance. GOMES, Luiz Flávio. Juizados especiais criminais: comentários à lei 9.0955, de 26.09.1995. 4. ed. São Paulo: Revista dos Tribunais, 2002. P. 155.

18 CAPEZ, Fernando. Curso de processo penal. 19. ed. São Paulo: Saraiva, 2012. P. 158.
} 
CHAGAS, Cleverton Paulo das e DIAS, Bruno Smolarek. A transação penal à luz da hermeneutica constitucional e processual penal. Revista Eletrônica Direito e Política, Programa de Pós-Graduação Stricto Sensu em Ciência Jurídica da UNIVALI, Itajaí, v.10, n.3, $2^{\circ}$ quadrimestre de 2015. Disponível em: www.univali.br/direitoepolitica - ISSN 1980-7791.

\subsection{Do descumprimento da transação penal}

Considerando a mitigação dos princípios do contraditório, da ampla defesa e do devido processo legal existente quando da aplicação da transação penal, se o autor do fato descumprir injustificadamente a medida, não pode ele ser de imediato preso pela conversão da pena acordada em privativa de liberdade. Assim, com o descumprimento, só resta pelo representante do Ministério Público iniciar a persecução penal, na forma do artigo 77 da lei 9.099/95, oferecendo a denúncia, ou requisitando as diligências que entender necessárias.

Segundo CAPEZ:

Em caso de descumprimento da pena restritiva de direitos imposta em virtude de transação penal, não cabe falar em conversão em pena privativa de liberdade, já que, se assim ocorresse, haveria ofensa ao princípio de que ninguém será privado de sua liberdade sem o devido processo legal (CF, art. 50, LIV). No lugar da conversão, deve o juiz determinar a abertura de vista ao Ministério Público para oferecimento da denúncia e instauração de processo-crime ${ }^{19}$.

Observa-se, portanto, que o mero descumprimento da transação penal não enseja em espécie semelhante a regressão de regime, levando o indivíduo a cadeia. Diferente disse, o que ocorre é que o Ministério Público passa possuir a prerrogativa de denunciar o autor do fato, instaurando contra ele a ação penal que, futuramente poderá gerar uma condenação em desfavor deste.

Cabe salientar que o descumprimento da transação penal acordada não poderá influenciar negativa ou positivamente quando da prolação da sentença pelo magistrado, sendo necessário a realização de diligências a fim de produzir provas que serão usadas para fundamentar a sentença.

\section{DISCRICIONARIDADE REGRADA DO MINISTÉRIO PÚBLICO}

$\mathrm{Na}$ aplicação da transação penal, alguns princípios fundamentais do processo penal são mitigados como por exemplo o contraditório, a ampla defesa, a

${ }^{19}$ CAPEZ, Fernando. Curso de processo penal. 19. ed. São Paulo: Saraiva, 2012. P. 616. 
CHAGAS, Cleverton Paulo das e DIAS, Bruno Smolarek. A transação penal à luz da hermeneutica constitucional e processual penal. Revista Eletrônica Direito e Política, Programa de Pós-Graduação Stricto Sensu em Ciência Jurídica da UNIVALI, Itajaí, v.10, n.3, $2^{\circ}$ quadrimestre de 2015. Disponível em: www.univali.br/direitoepolitica - ISSN 1980-7791.

presunção de inocência e a indisponibilidade da ação penal. Nesse último caso, o representante do Ministério Público dispõe da ação penal contra o autor do fato, oferecendo-Ihe em substituição a aplicação imediata de pena privativa de direito, desde que satisfeitos os requisitos do artigo 76 da lei 9.099/95. No momento em que o titular da ação penal abre mão desta, por estarem presentes referidos requisitos, este está obrigado a oferecer a transação penal na forma prevista em lei, tendo em vista que tal liberdade, em verdade, é uma liberdade regrada, ou, ainda, uma discricionariedade regrada.

Salienta CAPEZ:

A possibilidade de transação penal (proposta de aplicação de pena não privativa de liberdade) está regulamentada pelo art. 76 da lei 9.099/95, substituindo, nestas infrações penais, o princípio da obrigatoriedade pelo da discricionariedade regrada (o Ministério Público passa a ter liberdade para dispor da ação penal, embora esta liberdade não seja absoluta, mas limitada às hipóteses legais) ${ }^{20}$.

Ainda, ressalta o mesmo autor:

Com efeito, preenchidos os pressupostos legais, o representante do Ministério Público pode, movido por critérios de conveniência e oportunidade, deixar de oferecer a denúncia e propor um acordo penal com o autor do fato, ainda não acusado. Tal discricionariedade, contudo, não é plena, ilimitada, absoluta, pois depende de estarem preenchidos os requisitos legais, daí ser chamada pela doutrina de discricionariedade regrada ${ }^{21}$.

Portanto, mister verificar que a transação penal não é direito potestativo do autor do fato, dependendo do interesse do Ministério Público em oferecer-lhe tal benesse caso estejam presentes os requisitos autorizador do art. 76 da Lei 9.099/95.

${ }^{20}$ CAPEZ, Fernando. Curso de processo penal. 19. ed. São Paulo: Saraiva, 2012. P. 162.

${ }^{21}$ Idem. P. 163. 
CHAGAS, Cleverton Paulo das e DIAS, Bruno Smolarek. A transação penal à luz da hermeneutica constitucional e processual penal. Revista Eletrônica Direito e Política, Programa de Pós-Graduação Stricto Sensu em Ciência Jurídica da UNIVALI, Itajaí, v.10, n.3, $2^{\circ}$ quadrimestre de 2015. Disponível em: www.univali.br/direitoepolitica - ISSN 1980-7791.

\section{8. (IN) CONSTITUCIONALIDADE DA TRANSAÇÃO PENAL}

Inicialmente, mister enfatizar que a Constituição da República trouxe diversos direitos e garantias considerados fundamentais a todo indivíduo. Tais direitos e garantias, além de garantir o mínimo necessário para o cidadão, também estrutura o próprio estado.

Nesse sentido, a Constituição brasileira é doutrinariamente classificada como: escrita, formal, legal, dogmática, promulgada, rígida e analítica. Além desta classificação, extrai-se que esta é norteada em fundamentos, como: a soberania, a cidadania, a dignidade da pessoa humana, da livre iniciativa, entre outros. Deste modo, para possuir validade, todas as normas devem estar de acordo com a Constituição, sendo função dela, inclusive, disciplinar a competência para a aplicação da transação penal.

Desta maneira, nossa lei maior cumpre um papel basilar na estrutura do cenário jurídico e vincula todas as demais normas, definidas como infraconstitucionais. Logo, a inconstitucionalidade seria o desfecho inevitável no caso de descumprimento da observância desta vinculação com a carta magna.

Neste diapasão, muito se tem discutido acerca da constitucionalidade do instituto da transação penal. Tais discussões justificam-se pela peculiar mitigação de alguns dos princípios assegurados pela própria constituição, ganhando ainda mais folego quando substitui-se estes princípios por outros que, não raras vezes, deixam de cumprir como o papel a que se propõem.

Em termos práticos, troca-se o devido processo legal pelo princípio da oportunidade regrada do Ministério Público, este que nem sempre acompanha cabalmente a tramitação da demanda, visto que a grande maioria dos procedimentos dos juizados é orquestrada pela figura do conciliador, ao qual incumbe-se o papel de tentar a composição entre as partes, oferecer a transação penal, homologa-la e requisitar diligências quando carecer destas, fazendo, assim, as vezes do promotor, do magistrado e do conciliador.

De igual sorte, troca-se a busca da verdade real pela celeridade e agilidade na tramitação do feito, acarretando na ínfima ou inexistente investigação dos fatos. Outro aspecto que dá força a discussão está na natureza jurídica da transação penal. De um lado, parte da doutrina entende que a transação penal não possui 
CHAGAS, Cleverton Paulo das e DIAS, Bruno Smolarek. A transação penal à luz da hermeneutica constitucional e processual penal. Revista Eletrônica Direito e Política, Programa de Pós-Graduação Stricto Sensu em Ciência Jurídica da UNIVALI, Itajaí, v.10, n.3, $2^{\circ}$ quadrimestre de 2015. Disponível em: www.univali.br/direitoepolitica - ISSN 1980-7791.

caráter de pena, pois não há a formação de processo e, por consequência, também não há sentença condenatória. Para estes doutrinadores, a transação penal é um mero acordo entre o autor do fato e o Ministério Público visando evitar o oferecimento de denúncia - característica do sistema da justiça consensual. De outro lado, parte da doutrina entende que a transação penal seria, sim, pena, visto que obriga o autor do fato a cumprir determinada obrigação, sendo que a própria sentença de homologação da transação penal recebe a nomenclatura de "sentença". Entendem estes doutrinadores que o modelo consensual de justiça, em verdade, nada tem de consensual, considerando que o autor do fato, muitas vezes, aceita as condições de uma "pena" não privativa de liberdade por medo das consequências do um futuro processo.

Nessa linha de raciocínio, esclarece PACELLI:

O modelo consensual de justiça, sobretudo quando ainda atrelado à imposição de penas, abre-se a críticas de toda ordem. A informalidade e a preocupação com a funcionalidade do sistema (consensual) podem atingir níveis perturbadores de irracionalidade ${ }^{22}$.

Observa-se, portanto, que o grande argumento dos defensores da inconstitucionalidade da transação penal encontra-se na mitigação de princípios indispensáveis no procedimento comum. Desta feita, mister analisar as principais mitigações inerentes aos procedimentos dos Juizados Especiais Criminais, mormente no que se refere à transação penal.

\subsection{Princípios constitucionais mitigados}

Assim como todas as normas presente no ordenamento jurídico, a lei 9.099/95 também deve respeitar os princípios constitucionais e os princípios do processo penal, incluindo nesse caso, a transação penal.

Ao referir-se ao Juizado Especial Criminal, a Constituição Federal Brasileira o fez nos seguintes termos:

Art. 98. A União, no Distrito Federal e nos Territórios, e os

22 OLIVEIRA, Eugênio Pacelli de Oliveira. Curso de processo penal. 15. ed. Rio de Janeiro: Lumen Juris, 2011. P. 733. 
CHAGAS, Cleverton Paulo das e DIAS, Bruno Smolarek. A transação penal à luz da hermeneutica constitucional e processual penal. Revista Eletrônica Direito e Política, Programa de Pós-Graduação Stricto Sensu em Ciência Jurídica da UNIVALI, Itajaí, v.10, n.3, $2^{\circ}$ quadrimestre de 2015. Disponível em: www.univali.br/direitoepolitica - ISSN 1980-7791.

Estados criarão: I - juizados especiais, providos por juízes togados, ou togados e leigos, competentes para conciliação, o julgamento e a execução de causas cíveis e menor potencial complexidade $\mathrm{e}$ infrações penais de menor potencial ofensivo, mediante os procedimentos oral $e$ sumaríssimo, permitidos, nas hipóteses previstas em lei, a transação e o julgamento de recursos por turmas de juízes de primeiro grau ${ }^{23}$.

A primeira vista, o disposto no citado artigo 98, afastaria por completo qualquer argumento tendente a arguir a inconstitucionalidade do instituto da transação penal. Entretanto, tal dispositivo, somente determinou a aplicação da transação, mas deixou de apontar os detalhes acerca desse instituto, o que foi feito posteriormente pela lei 9.099/95.

Nessa esteira, argumenta JARDIM e AMORIM:

Percebe-se que a Constituição apenas legitima o legislador ordinário a definir quais sejam as infrações de menor potencial ofensivo e regular seu procedimento, inclusive $o$ instituto da transação penal. A Constituição não nos diz quais seriam tais infrações e quais seriam as regras para seu processamento, inclusive no que se refere ao instituto da transação penal ${ }^{24}$.

Assim, antes de se tomar um posicionamento acerca da constitucionalidade ou não da transação penal, cabe analisar os princípios constitucionais e processuais envolvidos.

\subsubsection{Princípio do devido processo legal}

Como garantia constitucional, tal princípio compreende o conjunto de garantias de ordem que assegura às partes o exercício de sua faculdade e poderes de natureza processual e, ainda, legitimam a própria função jurisdicional.

\footnotetext{
${ }^{23}$ BRASIL. Constituição (1988). Constituição da República Federativa do Brasil: Promulgada em 05 de Outubro de 1988. 8. Ed. São Paulo: Revista dos Tribunais, 2003.

24 JARDIM, Afrânio Silva. AMORIM, Pierre Souto Maior Coutinho de. Direito processual penal:

estudos e pareceres. 12. ed. Rio de Janeiro: Lumen Juris, 2013. P. 647.
} 
CHAGAS, Cleverton Paulo das e DIAS, Bruno Smolarek. A transação penal à luz da hermeneutica constitucional e processual penal. Revista Eletrônica Direito e Política, Programa de Pós-Graduação Stricto Sensu em Ciência Jurídica da UNIVALI, Itajaí, v.10, n.3, $2^{\circ}$ quadrimestre de 2015. Disponível em: www.univali.br/direitoepolitica - ISSN 1980-7791.

Cumpre salientar o seguinte dispositivo constitucional:

Art. $5^{\circ}$ - Todos são iguais perante a lei, sem distinção de qualquer natureza, garantindo-se aos brasileiros e aos estrangeiros residentes no País a inviolabilidade do direito à vida, à liberdade, à igualdade, à segurança e à propriedade, nos seguintes termos:

$[\ldots]$

LIV - ninguém será privado da liberdade ou de seus bens sem o devido processo legal;

LV - aos litigantes, em processo judicial ou administrativo, e aos acusados em geral são assegurados o contraditório e a ampla defesa, como meios e recursos a ela inerentes ${ }^{25}$.

Desse modo, é indispensável que se garanta ao acusado à plenitude da defesa, consistente no direito de ser ouvido, ser informado de todos os atos processuais e de ter acesso à defesa técnica, não sendo privado de sua liberdade e de seus bens, sem a garantia de um processo desenvolvido na forma que estabelece a lei. De modo geral, o devido processo legal visa proteger o acusado contra a ação arbitraria do Estado, inclusive em relação ao procedimento da aplicação da transação penal, visto que antes mesmo de dar a oportunidade de o autor do fato se defender, já the é imputado uma pena, que embora não seja privativa de liberdade, ainda assim é pena.

Acerca dessa inobservância do devido processo legal, adverte JARDIM e AMORIM:

Outros problemas de constitucionalidade ainda poderiam ser apontados, na forma de transação penal apresentada pela lei 9099/95, como, por exemplo, a existência de pena sem processo, pois a transação penal é homologada antes do oferecimento da denúncia. Podemos, no entanto, englobar também esse problema na nítida violação ao devido processo legal, ampliando este conceito ${ }^{26}$.

Assim, não se pode argumentar no sentido da utilização do princípio da

\footnotetext{
${ }^{25}$ BRASIL. Constituição (1988). Constituição da República Federativa do Brasil: Promulgada em 05 de Outubro de 1988. 8. Ed. São Paulo: Revista dos Tribunais, 2003.

${ }^{26}$ JARDIM, Afrânio Silva. AMORIM, Pierre Souto Maior Coutinho de. Direito processual penal:

estudos e pareceres. 12. ed. Rio de Janeiro: Lumen Juris, 2013. P. 473.
} 
CHAGAS, Cleverton Paulo das e DIAS, Bruno Smolarek. A transação penal à luz da hermeneutica constitucional e processual penal. Revista Eletrônica Direito e Política, Programa de Pós-Graduação Stricto Sensu em Ciência Jurídica da UNIVALI, Itajaí, v.10, n.3, $2^{\circ}$ quadrimestre de 2015. Disponível em: www.univali.br/direitoepolitica - ISSN 1980-7791.

celeridade, primando pela rapidez no processo, ignorar os princípios constitucionais, restringindo-os. É o que ensina o mesmo autor:

A Constituição da República em nenhuma hipótese autorizou o legislador a dispensar o devido processo legal, com ampla defesa e contraditório, quando da previsão da aplicação da transação penal. Está lá, dito na moribunda Constituição em vigor, que "ninguém será privado da liberdade ou de seus bens sem o devido processo legal" (art. 50, inciso LIV, da $(\mathrm{CR})^{27}$.

No mesmo sentido, o Supremo Tribunal Federal, ao julgar caso semelhante, deferiu ordem de Habeas Corpus em favor do paciente, sobre o argumento de que, o devido processo legal não é respeitado no momento da conversão de pena resultante da transação penal:

EMENDA: HABEAS CORPUS. PACIENTE ACUSADO DOS CRIMES DOS ARTS. 129 E 147 DO CÓDIGO PENAL. CONSTRANGIMENTO ILEGAL QUE CONSISTIRIA NA CONVERSÃO, EM PRISÃO, DA PENA DE DOAR CERTA QUANTIDADE DE ALIMENTO À "CASA DA CRIANÇA", RESULTANTE DE TRANSAÇÃO, QUE NÃO FOI CUMPRIDA. ALEGADA OFENSA AO PRINCÍPIO DO DEVIDO PROCESSO LEGAL. Conversão que, se mantida, valeria pela possibilidade de privar-se da liberdade de locomoção quem não foi condenado, em processo regular, sob as garantias do contraditório e da ampla defesa, como exigido nos incs. LIV, LV e LVII do art. $5^{\circ}$ da Constituição Federal. Habeas corpus deferido ${ }^{28}$.

Dessa maneira, o procedimento da transação penal, imposto pela lei 9.099/95, fere manifestamente o preceito constitucional do devido processo legal, tendo em vista que mesmo antes de acusar alguém por um ato criminoso, com o

\footnotetext{
27 JARDIM, Afrânio Silva. AMORIM, Pierre Souto Maior Coutinho de. Direito processual penal: estudos e pareceres. 12. ed. Rio de Janeiro: Lumen Juris, 2013. P. 475.

${ }^{28}$ BRASIL. SUPREMO TRIBUNAL FEDERAL. HC 80164 / MS - MATO GROSSO DO SUL, Relator Min. ILMAR GALVÃO, julgamento: 26/09/2000, Órgão Julgador: Primeira Turma. Disponível em: Http://www.stf.gov.br/portal/jurisprudência/listarjurisprudencia.asp
} 
CHAGAS, Cleverton Paulo das e DIAS, Bruno Smolarek. A transação penal à luz da hermeneutica constitucional e processual penal. Revista Eletrônica Direito e Política, Programa de Pós-Graduação Stricto Sensu em Ciência Jurídica da UNIVALI, Itajaí, v.10, n.3, $2^{\circ}$ quadrimestre de 2015. Disponível em: www.univali.br/direitoepolitica - ISSN 1980-7791.

oferecimento da denúncia, já lhe é imposto uma pena.

\subsubsection{Princípio da ampla defesa}

Trata-se da garantia que oferecida ao réu para lhe possibilitar trazer para o processo todos os elementos tendentes a esclarecer a verdade. Explica CAPEZ:

Implica o dever de o Estado proporcionar a todo acusado a mais completa defesa, seja pessoal (autodefesa), seja técnica (efetuado por defensor) (CF, art. 50, LXXIV). Desse princípio também decorre a obrigatoriedade de se observar à ordem natural do processo, de modo que a defesa se manifeste sempre em último lugar ${ }^{29}$.

Assim sendo, a busca por uma solução consensual para a demanda não é satisfatória, na medida em que há uma troca de permissões entre o suposto autor do fato e o Ministério Público. Aquele abriria mão de seu direito de ter uma defesa ampla e contraditório e este se inclinaria de uma pena privativa de liberdade.

Observa-se também que no processo de oferecimento e aplicação da transação penal ao suposto autor do fato, opera verdadeiramente uma pressão desiquilibrada sobre o autor, visto que, em muitas situações este somente aceita se submeter a aplicação imediata de pena privativa de direito por medo de uma punição mais severa no caso da recusa.

Disciplina JARDIM e AMORIM:

Pois bem. Nesse quadro, ao chegar à audiência preliminar, diante de um Juiz e de um membro do Ministério Público, o autor do fato é perguntado se deseja aceitar a transação penal, com todos os seus fogos de artifício (não aceitação de culpa, não gera reincidência, não traz os efeitos normais de uma sentença condenatória, etc.), percebendo uma pena restritiva de direito, ou se vai "enfrentar" o processo, neste último caso, quase como se fosse enfrentar o Juiz e o Ministério Público, tal é o inconveniente indisfarçável gerado

${ }^{29}$ CAPEZ, Fernando. Curso de processo penal. 19. ed. São Paulo: Saraiva, 2012. P. 235. 
CHAGAS, Cleverton Paulo das e DIAS, Bruno Smolarek. A transação penal à luz da hermeneutica constitucional e processual penal. Revista Eletrônica Direito e Política, Programa de Pós-Graduação Stricto Sensu em Ciência Jurídica da UNIVALI, Itajaí, v.10, n.3, $2^{\circ}$ quadrimestre de 2015. Disponível em: www.univali.br/direitoepolitica - ISSN 1980-7791.

$$
\text { por quem não aceita a "benéfica" proposta }{ }^{30} \text {. }
$$

Como visto, a ampla defesa se quer é analisada, visto que o autor do fato não tem assegurado o direito de trazer aos autos elementos que possam mostrar a verdade fática.

\subsubsection{Princípio do contraditório}

Por este princípio, toda vez que for oposto um argumento contra determinada pessoa, esta terá a oportunidade de se pronunciar sobre o argumento, não podendo nada ser decidido antes de tal oportunidade. A inobservância deste princípio gera nulidade do feito, como prevê o art. 564, III, do CPP.

Caso contrário, o que se veria seria um cenário de posições distintas em que uma parte se beneficia em detrimento da outra.

Nas palavras de CAPEZ:

A bilateralidade da ação gera a bilateralidade do processo, de modo que as partes, em relação ao juiz, não são antagônicas, mas colaboradoras necessárias. O juiz colocase, na atividade que lhe incube o estado Juiz, equidistante das partes, só poderá dizer que o direito preexistente foi devidamente aplicado ao caso concreto se, ouvida uma parte, for dá a outra parte manifestar-se em seguida. Por isso, o princípio é identificado na doutrina pelo binômio ciência e participação ${ }^{31}$.

Assim, não pode a defesa sofre prejuízos irreparáveis pela falta da possibilidade de se manifestar.

Mister enfatizar que o princípio do contraditório decorre do processo do tipo acusatório, onde as partes, acusadora e acusada, encontram-se em pé de igualdade, com os mesmos direitos.

Entretanto, é patente o desrespeito a este princípio fundamental no momento da homologação da proposta de transação penal, tendo em vista que o suposto autor do fato tem de escolher pela diminuição de seus direitos ou enfrentar o

30 JARDIM, Afrânio Silva. AMORIM, Pierre Souto Maior Coutinho de. Direito processual penal: estudos e pareceres. 12. ed. Rio de Janeiro: Lumen Juris, 2013. P. 313.

${ }^{31}$ CAPEZ, Fernando. Curso de processo penal. 19. ed. São Paulo: Saraiva, 2012. P. 322. 
CHAGAS, Cleverton Paulo das e DIAS, Bruno Smolarek. A transação penal à luz da hermeneutica constitucional e processual penal. Revista Eletrônica Direito e Política, Programa de Pós-Graduação Stricto Sensu em Ciência Jurídica da UNIVALI, Itajaí, v.10, n.3, $2^{\circ}$ quadrimestre de 2015. Disponível em: www.univali.br/direitoepolitica - ISSN 1980-7791.

processo, sem ter sido ouvido ou ter produzido qualquer tipo de prova em seu favor, em resposta ao contido no Termo Circunstanciado de Ocorrência.

Desse modo, é visível a inconstitucionalidade da transação penal, pois o indivíduo não pode dispor de uma garantia individual constitucionalmente assegurada, por ser absolutamente indeclinável.

Ademais, para se exercer o direito de punir pelo Estado é indispensável que a existência precedentes de processo em julgado, visto que não pode ser imposto arbitrariamente a sanção.

\subsection{Princípio processuais mitigados}

\subsubsection{Princípio da presunção de inocência}

Consequência do princípio do devido processo legal, a Constituição Federal não presume a inocência, mas declara que "ninguém será considerado culpado até o trânsito em julgado de sentença penal condenatória" (art. 50, inciso LVII). Assim, deve ocorrer a inversão do ônus da prova, ou seja, a inocência é presumida, cabendo ao Ministério Público provar a culpa, caso contrário, a ação deve ser considerada improcedente.

Como visto, na transação penal o autor do fato recebe uma pena, ainda que restritiva de direito, sem uma análise profunda dos fatos, sem direito de defesa, ou, ao menos, a instauração de processo na sua devida forma e por consequência, sem sentença condenatória.

Deste modo, é evidente que não pode ser aceito, mesmo que em nome da celeridade processual, instituir a inobservância das garantias constitucionais do cidadão, impondo a aceitação da aplicação antecipada de pena.

\subsubsection{Princípio da obrigatoriedade da ação}

Na contramão do princípio da obrigatoriedade da ação, a lei dos juizados especiais criminais passou a aplicar no direito o critério da oportunidade regulada pela lei, rompendo como exigência severa da ação penal em todas as espécies de crimes. 
CHAGAS, Cleverton Paulo das e DIAS, Bruno Smolarek. A transação penal à luz da hermeneutica constitucional e processual penal. Revista Eletrônica Direito e Política, Programa de Pós-Graduação Stricto Sensu em Ciência Jurídica da UNIVALI, Itajaí, v.10, n.3, $2^{\circ}$ quadrimestre de 2015. Disponível em: www.univali.br/direitoepolitica - ISSN 1980-7791.

O conceito da obrigatoriedade da ação é melhor definido nas palavras de TOURINHO NETO:

A lei dos Juizados Especiais, ao admitir a transação, abranda o princípio da obrigatoriedade da ação penal. Pelo princípio da obrigatoriedade ou legalidade (legaitatsprinzip), se estiver demonstrada a tipicidade, a materialidade do crime e se houver indícios suficientes de autoria, salvo se ocorrer causa excludente de ilicitude, de extinção da punibilidade, ou quando presente o princípio da insignificância, crime de bagatela - o Estado não se preocupa com as coisas mínimas (mínima non curat praetor) - o órgão ministerial está obrigado a oferecer a denúncia, pois os delitos não podem ficar impunes (nec delicta maneant impunita) ${ }^{32}$.

Nesta esteira, o Ministério Público, ao propor a transação penal afasta a obrigatoriedade - com a permissão do legislador - valorizando o princípio da oportunidade, tornando-se facultativo o exercício da ação penal.

Sobre o tema, argumenta JESUS:

Adotou-se o princípio da "oportunidade regrada. O Ministério Público aprecia a conveniência de não ser proposta a ação penal, oferendo ao autor do fato o imediato encerramento do procedimento pela aceitação de pena menos severa. Esse mister, entretanto, não é absoluto. Não existe p. ex., em relação a todas as infrações penais. Sujeita-se a regras legais ${ }^{33}$.

Ao referir-se a expressão "discricionariedade regrada" trata-se de situação em que a lei é que diz quando será possível a aplicação da transação e, também, de que modo ela deve ser feita. Entretanto, discute-se na doutrina se tal proposta seria ou não uma faculdade do órgão ministerial, sendo, em caso negativo cabível habeas corpus ou mandado de segurança em favor do indivíduo prejudicado pelo não oferecimento da transação.

\footnotetext{
32 TOURINHO NETO, Fernando da Costa. Juizados especiais estaduais cíveis e criminais: comentários à Lei 9.099/95. 5. ed. São Paulo: Editora Revista dos Tribunais, 2007. P. 546. 33 JESUS, Damásio de. Lei dos Juizados Especiais Criminais Anotada. 4. ed. São Paulo: Saraiva, 1997, p. 75.
} 
CHAGAS, Cleverton Paulo das e DIAS, Bruno Smolarek. A transação penal à luz da hermeneutica constitucional e processual penal. Revista Eletrônica Direito e Política, Programa de Pós-Graduação Stricto Sensu em Ciência Jurídica da UNIVALI, Itajaí, v.10, n.3, $2^{\circ}$ quadrimestre de 2015. Disponível em: www.univali.br/direitoepolitica - ISSN 1980-7791.

\section{POSICIONAMENTOS JURISPRUDENCIAIS}

No que tange aos entendimentos dos tribunais, e neste caso, aqueles cujos julgamentos mais influenciam nas decisões dos julgadores, diga-se o Superior Tribunal de Justiça e o Supremo Tribunal Federal, merece importante destaque o diferente entendimento destes dois órgãos sobre a questão da transação penal. Para o STJ, a sentença do Juiz que homologa a transação penal tem eficácia condenatória tem eficácia condenatória e, por esta razão, gera a extinção da pretensão punitiva. O descumprimento dos termos do acordo, assim, irradiaria tais quais o descumprimento das condições de penas restritivas de direito, possibilitando, inclusive, eventual conversão em pena privativa de liberdade.

Para ilustrar esse entendimento, destacam-se dois julgados da referida corte, nos termos que seguem:

HABEAS CORPUS. DIREITO PENAL. FURTO TENTADO. TRANSAÇÃO PENAL ACEITA E HOMOLOGADA. REVOGAÇÃO. INCABIMENTO.

ORDEM

CONCEDIDA.

1. "A sentença homologatória da transação penal, prevista no art. 76 da Lei no 9.099/95, tem natureza condenatória e gera eficácia de coisa julgada material e formal, obstando a instauração de ação penal contra o autor do fato, se descumprido o acordo homologado." (HC no 33.487/SP, Relator Ministro Gilson Dipp, in DJ 10/7/2004).

2. Ordem concedida ${ }^{34}$.

No mesmo sentido:

HABEAS CORPUS. DIREITO PROCESSUAL PENAL. DELITO DE TRÂNSITO. CRIME DE MENOR POTENCIAL OFENSIVO. TRANSAÇÃO PENAL. ACEITAÇÃO. APLICAÇÃO DE PENA DE MULTA. INADIMPLEMENTO. OCORRÊNCIA. OFERECIMENTO DA DENÚNCIA. INCABIMENTO. ORDEM CONCEDIDA. 1. É firme a jurisprudência do Excelso Supremo Tribunal

\footnotetext{
34 BRASIL. HC 72.671/RJ, Rel. Ministro HAMILTON CARVALHIDO, SEXTA TURMA, julgado em 30/08/2007, DJe 04/08/2008.
} 
CHAGAS, Cleverton Paulo das e DIAS, Bruno Smolarek. A transação penal à luz da hermeneutica constitucional e processual penal. Revista Eletrônica Direito e Política, Programa de Pós-Graduação Stricto Sensu em Ciência Jurídica da UNIVALI, Itajaí, v.10, n.3, $2^{\circ}$ quadrimestre de 2015. Disponível em: www.univali.br/direitoepolitica - ISSN 1980-7791.

Federal e a deste Superior Tribunal de Justiça no sentido de afirmar o incabimento de propositura de ação penal, na hipótese de descumprimento da transação penal (artigo 76 da Lei no 9.099/95).

2. Ressalva de entendimento contrário do Relator. 3. Ordem concedida ${ }^{35}$.

Em sentido contrário, a jurisprudência do STF considera descabida a conversão da pena restritiva de direitos oriunda de transação penal em privativa de liberdade, pois entendo que a sentença de homologação não tem natureza condenatória, restando ao Ministério Público tão somente o oferecimento da denúncia em desfavor do autor do fato.

Esse posicionamento também é facilmente encontrado nos julgados do STF, como vemos:

HABEAS CORPUS. CRIME DE LESÃO CORPUS. CRIME DE LESÃO CORPORAL LEVE CONTRA IDOSO. TRANSAÇÃO PENAL. NÃO-CUMPRIMENTO DE PENA RESTRITIVA DE DIREITOS. NÃO COMETIMENTO DE CRIME DE DESOBEDIÊNCIA.

A jurisprudência deste Supremo Tribunal é firme no sentido de que o descumprimento da transação pena a que alude o art. 76 da Lei no 9.099/95 gera a submissão do processo ao seu estado anterior, oportunizando-se ao Ministério Público a propositura da ação acusatória. Não há que se cogitar, portanto, da propositura de nova ação criminal, desta feita por ofensa ao art. 330 do CP. Ordem concedida para determinar o trancamento da ação penal pelo crime de desobediência ${ }^{36}$.

Percebe-se que, embora muito se fale em unificação de entendimentos, ainda existe uma discrepância muito grande entre as orientações jurisprudenciais das

\footnotetext{
${ }^{35}$ BRASIL. HC 60.941/MG, Rel. Ministro HAMILTON CARVALHIDO, SEXTA TURMA, julgado em 21/09/2006, DJ 09/04/2007 p. 276.

${ }^{36}$ BRASIL. SUPREMO TRIBUNAL FEDERAL. HC 84976, Relator(a): Min. CARLOS BRITTO, Primeira Turma, julgado em 20/09/2005.
} 
CHAGAS, Cleverton Paulo das e DIAS, Bruno Smolarek. A transação penal à luz da hermeneutica constitucional e processual penal. Revista Eletrônica Direito e Política, Programa de Pós-Graduação Stricto Sensu em Ciência Jurídica da UNIVALI, Itajaí, v.10, n.3, $2^{\circ}$ quadrimestre de 2015. Disponível em: www.univali.br/direitoepolitica - ISSN 1980-7791.

duas maiores cortes do país.

É patente a divergência de entendimentos entre as duas casas, sendo visivelmente antagônica. Em termos práticos, o juiz tem a árdua missão de conciliar estes dois entendimentos no caso concreto. Nesse sentido, muitos magistrados ao tomarem conhecimento da transação penal, suspendem o processo até seu cumprimento, sem homologar o acordo. Dessa forma, não há sentença constituído título executivo sobre a avença; sendo ela descumprida, retorna-se o andamento do processo com denúncia. No caso de cumprimento integral, homologa-se a transação, extinguindo-se a punibilidade.

\section{CONSIDERAÇÕES FINAIS}

Extrai-se do trabalho desenvolvido, importantes apontamentos acerca de um inovador instituto consagrado pela lei (e determinado pela Constituição), qual seja, a transação penal, no âmbito do Juizado Especial Criminal.

Restou-se invocados todos os aspectos que orbitam em torno deste dispositivo legal, mormente o momento e a maneira que deveria a transação ser aplicada no caso em concreto.

Questionou-se se a aplicação deste instituto despenalizante antes mesmo da instauração da ação penal incorreria em desrespeito à Constituição e as premissas fundamentais nela contidas, a exemplo do contraditório, do devido processo legal, da ampla defesa, entre outros.

É indubitável a adesão jurídica a meios que tornem as demandas criminais mas céleres, pois o abarrotamento do sistema, devido ao acumulo de processos, torna a justiça mais morosa e, não raras vezes, ineficaz.

De igual sorte, é inquestionável a pressão feita pela sociedade para que o estado assegure o fiel cumprimento dos direitos fundamentais e as garantias que deles decorrem, como por exemplo a segurança jurídica.

Neste contexto de divergências e, até mesmo de certa contradição, a lei dos Juizados Especiais Cíveis e Criminais criou o instituto da transação penal, numa tentativa do legislador de tornar a tramitação das contravenções penais e crimes de menor potencial ofensivo mais rápida e informal. Junto com este instituto, trouxe-se à baila diversas críticas e questionamentos, especialmente do que diz 
CHAGAS, Cleverton Paulo das e DIAS, Bruno Smolarek. A transação penal à luz da hermeneutica constitucional e processual penal. Revista Eletrônica Direito e Política, Programa de Pós-Graduação Stricto Sensu em Ciência Jurídica da UNIVALI, Itajaí, v.10, n.3, $2^{\circ}$ quadrimestre de 2015. Disponível em: www.univali.br/direitoepolitica - ISSN 1980-7791.

respeito à ponderação (ou confronto) entre a busca de procedimentos mais rápidos e econômicos, processualmente falando, e a manutenção do equilíbrio jurídico como o devido respeito às normas hierarquicamente consagradas.

Restou evidenciado que a transação penal incorre em dúvidas acerca de sua constitucionalidade, fundamentalmente quando de sua aplicação (oferecimento e aceitação) e sua homologação pelo magistrado a qual mitiga em certo ponto as garantias do devido processo legal, do contraditório e da ampla defesa, embora o próprio direito constitucional em momento algum fale sobre a mitigação de direitos fundamentais, tal qual ocorre com a aplicação da transação penal.

Ressalta-se que a Lei somente pode condenar 0 indivíduo que for comprovadamente culpado pela pratica de determinado crime, garantindo-lhe acesso a todos os meios de defesa e seguindo os procedimentos constitucionais. Extrai-se da análise realizada que na transação penal ocorre um desapego ao procedimento normalmente adotado.

Da análise e ponderação dos argumentos doutrinários, conclui-se que para uma correta aplicação da transação penal, deve-se ocorrer uma reestruturação desse instituto, buscando garantir o fiel cumprimento de todos os princípios fundamentais determinados pela Constituição com especial atenção à segurança jurídica.

Nesse sentido, a mitigação de qualquer dos princípios constitucionais ou processuais penais, conforme demonstrado ao longo do trabalho, não merece prosperar, pois representa verdadeira e inadmissível afronta ao estado democrático de direito. Não se pode suprimir do homem, mesmo que baseado nos mais atraentes argumentos, direitos e garantias conquistados a duras penas, resultado de séculos de batalhas na busca da própria dignidade da pessoa humana e ao custo do sangue, do suor e das lágrimas de nossos antepassados. Batalhas estas que tomamos como herança e ainda hoje lutamos, visando mais direitos, mais conquistas. Não pode o estado legislador tornar-se seu própria algoz, mitigando e suprimindo do indivíduo que por uma infelicidade do destino encontre-se na figura do autor do fato, como equivocadamente chama a lei dos Juizados Especiais Criminais, direitos e garantias inerentes a qualquer pessoa, tais como o contraditório, a ampla defesa e o devido processo legal.

Adota-se, portanto o posicionamento de que a transação penal nos Juizados 
CHAGAS, Cleverton Paulo das e DIAS, Bruno Smolarek. A transação penal à luz da hermeneutica constitucional e processual penal. Revista Eletrônica Direito e Política, Programa de Pós-Graduação Stricto Sensu em Ciência Jurídica da UNIVALI, Itajaí, v.10, n.3, $2^{\circ}$ quadrimestre de 2015. Disponível em: www.univali.br/direitoepolitica - ISSN 1980-7791.

Especiais Criminais é, sim, um instituto possível, que visa maior celeridade no judiciário e representa um benefício e uma importante conquista. Todavia, para que seja justa, carece de reformas, atendendo o devido processo legal e respeitando os demais princípios e direitos fundamentais. Para tanto, é necessária uma maior atuação do Supremo Tribunal Federal e do Superior Tribunal de Justiça, determinando novos parâmetros para a aplicação correta da transação penal, pacificando a questão.

Conclui-se, por último e por todo o exposto, que a proposta de transação penal pelo Ministério Público, deve se dar após o oferecimento da denúncia e somente pode ser feita após dar oportunidade de defesa ao acusado, mesmo que de forma mais célere e informal, bem como que a sentença homologatória da transação, deve ser proferida após o integral cumprimento das condições acordadas, visto que uma vez homologada, gera a extinção da punibilidade e, por consequência, impossibilidade de retorno ao status quo ante.

\section{REFERÊNCIAS DAS FONTES CITADAS}

BRASIL. Constituição (1988). Constituição da República Federativa do Brasil: Promulgada em 05 de Outubro de 1988. 8. Ed. São Paulo: Revista dos Tribunais, 2003.

BRASIL. HC 60.941/MG, Rel. Ministro HAMILTON CARVALHIDO, SEXTA TURMA, julgado em 21/09/2006, DJ 09/04/2007 p. 276.

BRASIL. HC 72.671/RJ, Rel. Ministro HAMILTON CARVALHIDO, SEXTA TURMA, julgado em 30/08/2007, DJe 04/08/2008.

BRASIL. SUPREMO TRIBUNAL FEDERAL. HC 80164 / MS - MATO GROSSO DO SUL, Relator Min. ILMAR GALVÃO, julgamento: 26/09/2000, Órgão Julgador: Primeira Turma. Disponível em: Http://www.stf.gov.br/portal/jurisprudência/listarjurisprudencia.asp

BRASIL. SUPREMO TRIBUNAL FEDERAL. HC 84976, Relator(a): Min. CARLOS 
CHAGAS, Cleverton Paulo das e DIAS, Bruno Smolarek. A transação penal à luz da hermeneutica constitucional e processual penal. Revista Eletrônica Direito e Política, Programa de Pós-Graduação Stricto Sensu em Ciência Jurídica da UNIVALI, Itajaí, v.10, n.3, $2^{\circ}$ quadrimestre de 2015. Disponível em: www.univali.br/direitoepolitica - ISSN 1980-7791.

BRITTO, Primeira Turma, julgado em 20/09/2005.

CAPEZ, Fernando. Curso de processo penal. 19. ed. São Paulo: Saraiva, 2012.

CARVALHO, Luiz Gustavo Grandinetti Castanho. Lei dos Juizados Especiais Criminais Comentada, anotada e atualizada de acordo com a Lei 10.259/2001. 3 ed. Rio de Janeiro: Lúmen Júris.

GRINOVER, Ada Pellegrini. FILHO, Antônio Magalhões Gomes. FERNANDES, Antônio Scarance. GOMES, Luiz Flávio. Juizados especiais criminais: comentários à lei 9.0955, de 26.09.1995. 4. ed. São Paulo: Revista dos Tribunais, 2002.

JARDIM, Afrânio Silva. AMORIM, Pierre Souto Maior Coutinho de. Direito processual penal: estudos e pareceres. 12. ed. Rio de Janeiro: Lumen Juris, 2013.

JESUS, Damásio de. Lei dos Juizados Especiais Criminais Anotada. 4. ed. São Paulo: Saraiva, 1997, p. 75.

JUNIOR, Aury Lopes, Direito processual penal. 9. ed. São Paulo: Saraiva, 2012.

MIRABETE, Julio Fabbrini. Juizados especiais criminais. 3. ed. São Paulo: Atlas S.A, 1998.

NOGUEIRA, Paulo Lucio. Juizados Especiais Cíveis e Criminais: comentários. São Paulo: Saraiva 1996.

NUCCI, Guilherme de Souza. Leis penais e processuais penais comentadas. 5. ed. São Paulo: Revista dos Tribunais, 2010.

OLIVEIRA, Eugênio Pacelli de Oliveira. Curso de processo penal. 15. ed. Rio de Janeiro: Lumen Juris, 2011.

TOURINHO NETO, Fernando da Costa. Juizados especiais estaduais cíveis e 
CHAGAS, Cleverton Paulo das e DIAS, Bruno Smolarek. A transação penal à luz da hermeneutica constitucional e processual penal. Revista Eletrônica Direito e Política, Programa de Pós-Graduação Stricto Sensu em Ciência Jurídica da UNIVALI, Itajaí, v.10, n.3, 20 quadrimestre de 2015. Disponível em: www.univali.br/direitoepolitica - ISSN 1980-7791.

criminais: comentários à Lei 9.099/95. 5. ed. São Paulo: Editora Revista dos Tribunais, 2007.

Submetido em: Maio/2015

Aprovado em: Julho/2015 